\title{
Genetic and environmental effects on scores of conformation, precocity and muscling in long yearling Nellore cattle
}

\author{
Efeitos genéticos e de ambiente sobre os escores visuais de \\ conformação, precocidade e musculosidade em bovinos Nelore ao \\ sobreano
}

\author{
Diego Barrozo'; Maira Mattar²; Patricia Tholon ${ }^{3}$; João Ademir de Oliveira ${ }^{4}$; \\ Daiane Cristina Becker Scalez ${ }^{5 *}$; Sandra Aidar de Queiroz ${ }^{6}$
}

\begin{abstract}
The visual scores for conformation $(\mathrm{C})$, precocity $(\mathrm{P})$ and muscle $(\mathrm{M})$ are used to indirectly assess traits related to termination and carcass composition. This study analyzes how age of dam at calving (AC), long yearling age (YA) and long yearling weight (YW) of the animal affect the scores of Nellore cattle, and estimates their heritability. Regression functions were estimated to determine the AC, YA and $\mathrm{YW}$ effects on $\mathrm{C}, \mathrm{P}$ and $\mathrm{M}$ scores after the contemporary group (CG) effect being absorbed. The heritabilities were estimated by restricted maximum likelihood using four different models that included animal additive genetic effect as random and different covariates (AC, YA and YW) as fixed effects. The regression analysis showed that the covariates, either linear or quadratic, significantly influenced the scores of C, P and M. The determination coefficients of the models for YA and AC were small, probably due to the $\mathrm{CG}$ bias removal. The heritability estimates for the scores ranged from 0.13 to 0.36 for $\mathrm{C}$; 0.32 to 0.36 for $\mathrm{P}$; and, 0.35 to 0.38 for $\mathrm{M}$, for all models, indicating that $\mathrm{C}, \mathrm{P}$ and $\mathrm{M}$ respond to direct selection. The classification of animals according to their breeding values, especially in relation to $\mathrm{C}$, varied according to the environmental effects included in the models.
\end{abstract}

Key words: Calving age, genetic evaluation, heritability, long yearling age, long yearling weight

\section{Resumo}

Os escores visuais de conformação $(\mathrm{C})$, precocidade $(\mathrm{P})$ e musculosidade $(\mathrm{M})$ são usados para acessar indiretamente características relacionadas à terminação e composição de carcaça. Neste estudo, objetivou-se analisar como a idade da vaca ao parto (AC), idade (YA) e peso do animal ao sobreano (YW) influenciam os escores de bovinos da raça Nelore, além de estimar suas herdabilidades. Foram estimadas funções de regressão dos efeitos de AC, YA e YW sobre os escores $\mathrm{C}, \mathrm{P}$ e M, após a absorção do efeito de grupo de contemporâneos (CG). As herdabilidades foram estimadas por máxima

\footnotetext{
${ }^{1}$ M.e em Genética e Melhoramento Animal, Faculdade de Ciências Agrárias e Veterinárias, Universidade Estadual Paulista “Júlio de Mesquita Filho", UNESP, Jaboticabal, SP, Brasil. Trabalha atualmente na Casa da Agricultura de Guaraci, Guaraci, SP, Brasil. E-mail: rodoxzoo@yahoo.com.br

2 Prof ${ }^{a}$ Dra $^{\mathrm{a}}$, Centro Universitário da Fundação Educacional de Barreto, UNIFEB, Barretos, SP, Brasil. E-mail: mattar@feb.br

3 Pesquisadora Dr ${ }^{\mathrm{a}}$, EMBRAPA Pecuária Sudeste, São Carlos, SP, Brasil. E-mail: patricia.tholon@embrapa.br

${ }^{4}$ Prof. Titular, Dept ${ }^{\circ}$ de Ciências Exatas, Faculdade de Ciências Agrárias e Veterinárias, Universidade Estadual Paulista “Júlio de Mesquita Filho", UNESP, Jaboticabal, SP, Brasil. E-mail: jaoliv@fcav.unesp.br

${ }^{5}$ Discente de Doutorado em Zootecnia em Genética e Melhoramento Animal, UNESP, Jaboticabal, SP, Brasil. E-mail: daianebecker@hotmail.com

${ }^{6}$ Prof $^{a}$ Adjunta, Dept ${ }^{\circ}$ de Zootecnia, UNESP, Jaboticabal, SP, Brasil. E-mail: saquei@fcav.unesp.br

* Author for correspondence
} 
verossimilhança restrita, considerando-se quatro diferentes modelos que incluíram o efeito genético aditivo de animal como aleatório, e diferentes covariáveis (AC, YA e YW) como efeitos fixos. Nas análises de regressão, as covariáveis, tanto linear como quadrática, influenciaram significativamente os escores C, P e M. Os coeficientes de determinação dos modelos para YA e AC foram de pequena magnitude, provavelmente devido à absorção do efeito de CG. As estimativas de herdabilidade para os escores variaram de 0,13 a 0,36 para $\mathrm{C}$, de 0,32 a 0,36 para $\mathrm{P}$, e de 0,35 a 0,38 para $\mathrm{M}$, considerando todos os modelos utilizados, indicando que $\mathrm{C}, \mathrm{P}$ e $\mathrm{M}$ respondem à seleção direta. A classificação dos animais de acordo com seus valores genéticos, principalmente em relação a $\mathrm{C}$, variou de acordo com os efeitos de ambiente incluídos nos modelos.

Palavras-chave: Avaliação genética, herdabilidade, idade ao sobreano, idade da vaca ao parto, peso ao sobreano

\section{Introduction}

The use of visual scores allows indirect evaluation related to early termination and carcass composition of beef cattle without either stressing out the animals or increasing the measurement costs of the parameters needed for genetic evaluation.

Conformation (C), precocity (P) and muscle (M) scores estimate the amount of meat produced if the animals were slaughtered at the time of evaluation, the animal's ability to accumulate the minimum amount of fat required for slaughtering without reaching high body weight and muscle mass present in the carcass, respectively (QUEIROZ et al., 2009). The use of scores to evaluate carcass traits in live animals was proposed by Long (1973) as an alternative to the exclusive selection by weight or weight gain, which is not enough to improve the performance and carcass quality of the animal after slaughter (QUEIROZ et al., 2009).

The genetic evaluation process requires that the selection of animals must be free from the influence of environmental effects and, therefore, these effects should be known and minimized or eliminated. Environmental effects can be divided into unpredictable, as the classificatory effect of contemporary group, and predictable, which are often used as covariates such as age at first calving, animal age and animal weight (CARDOSO et al., 2004). However, for the traits $C, P$ and $M$, measured by visual scores, there is no consensus in the literature on which environmental effects should be considered in the statistical models for the genetic evaluation of animals (DAL-FARRA et al., 2002; QUEIROZ et al., 2011). This study evaluates the influence of age of dam at calving (AC), long yearling age (YA) and long yearling weight (YW) on scores of $\mathrm{C}, \mathrm{P}$ and $\mathrm{M}$ at long yearling age and estimates the heritability of these scores using different models, with the aim of improving Nellore breeding programs.

\section{Material and Methods}

The data on body condition scores at long yearling age of Nellore population were provided by the PAINT ${ }^{\circledR}$ breeding beef cattle program of CRV Lagoa Ltd. The scores ranged from one to five for each trait assessed (C, P and M), as follows: "1" assigned to the worst animals, " 2 " to those whose traits were slightly below lot average, " 3 " to animals with average traits, "4" to those slightly above lot average, and " 5 " to the best cattle (CRV LAGOA, 2013).

The data consistency and statistical analysis were performed using the statistical software SAS ${ }^{\circledR}$ (SAS 9.1, SAS Institute, Cary, North Carolina, USA). Outliers; animals without $\mathrm{C}, \mathrm{P}$ or $\mathrm{M}$ information; animals of unknown parents; bulls with fewer than five sons and contemporary groups (CG) with less than five animals were eliminated. After this procedure, 58,947, 58,611 and 54,935 animals had available $\mathrm{C}, \mathrm{P}$ and $\mathrm{M}$ information on the traits, age of cow at calving (AC), age of animal at long yearling 
(YA) and long yearling weight (YW), respectively, distributed in 2752 contemporary groups.

CGs were formed from the concatenation of the data regarding animal birth farm, birth year, birth season (spring, summer, autumn, winter), sex, management group, weaning farm, weaning management group, long yearling farm and long yearling management group.

$\mathrm{AC}, \mathrm{YA}$ and $\mathrm{YW}$ influence on $\mathrm{C}, \mathrm{P}$ and $\mathrm{M}$ score was evaluated by regression analysis after absorbing the $\mathrm{CG}$ effect by subtracting their respective averages from each variable by $\mathrm{CG}$. These analyses aimed to assess the significance of different order models (linear and quadratic) for the same covariate (AC, YA and YW), similar to those reported by Cardoso et al. (2008). The models were determined by plotting the data to show the effect of each covariate on $\mathrm{C}, \mathrm{P}$ and $\mathrm{M}$ traits. The covariates order was changed until the highest determination coefficient $\left(\mathrm{R}^{2}\right)$ was achieved and, therefore, the highest level of significance of the solutions. The following model was used:

$$
Y_{i j}=b_{0}+b_{1} * Z_{j}+b_{2} * Z_{j}^{2}+\varepsilon
$$

where: $Y_{i j}=$ visual score predicted for the $i-t \boldsymbol{h}$ trait; $j=\mathrm{C}, \mathrm{P}$ and $\mathrm{M}$, under the effect of the $j-$ th trait; $b_{0}, b_{1}$ and $b_{2}=$ intercept, linear and quadratic regression coefficients, respectively; ${ }^{2}{ }_{j}^{2}=$ effect of the $\mathrm{j}$-th covariate on $Y_{i j} j=\mathrm{YA}, \mathrm{AC}$ and $\mathrm{YW} ; \boldsymbol{\varepsilon}=$ vector of residual random effects.

Heritabilities of C, P and M were estimated by Restricted Maximum Likelihood (REML) method, using the MTDFREML (BOLDMAN et al., 1995) software for a unitrait animal model, which can be represented by:

$$
Y=X b+Z a+\varepsilon
$$

where: $Y=$ vector of the dependent variable $(\mathrm{C}$, $\mathrm{P}$ or $\mathrm{M}) ; X=$ incidence matrix which combines the elements of $b$ to $Y ; b=$ vector of fixed effects (CG and covariate); $Z=$ incidence matrix which combines the elements of a to $Y$; $a=$ vector of random effects of direct additive genetic value; and $\boldsymbol{\varepsilon}=$ vector of residual random effects. The following assumptions were made:

$$
\begin{aligned}
& E[y]=X b \\
& E\left[\begin{array}{l}
g \\
e
\end{array}\right]=\left[\begin{array}{l}
0 \\
0
\end{array}\right] \operatorname{Var}\left[\begin{array}{l}
g \\
e
\end{array}\right]=\left[\begin{array}{cc}
A v_{g}^{2} & \mathbf{0} \\
\mathbf{0} & I v_{\theta}^{2}
\end{array}\right]
\end{aligned}
$$

where: $A=$ relationship matrix; $I=$ identity matrix; $v_{g}^{\mathbf{2}}=$ additive genetic variance; and, $v_{\theta}^{\mathbf{2}}=$ residual variance.

The $\mathrm{C}, \mathrm{P}$ and $\mathrm{M}$ scores were analyzed considering four different models, i.e., without covariates (model M1); and with the covariates long yearling age (linear and quadratic effects, M2 model), long yearling weight (linear and quadratic effects, M3 model) and long yearling weight (linear and quadratic effects) adjusted by multiplicative correction factors for 450 days of age ( $\mathrm{Ci}, \mathrm{Pi}$ and $\mathrm{Mi})$, as calculated by quadratic interpolation (model M4). The models did not include the effect of dam age at calving due to the low coefficient of determination achieved in the regression analyses and its limited importance to the long yearling traits. In all models and for all traits, CG and animal additive genetic effects were included as random.

Bulls with more than a hundred offspring were evaluated according to their breeding values predicted by the four different models. In order to compare models, Pearson correlation analysis was performed between animal breeding values and Spearman correlation between breeding value rankings.

\section{Results and Discussion}

The descriptive statistics (Table 1) show that when scores were adjusted to 450 days of age (Ci, Pi and Mi), the mean, standard deviation and maximum values were higher than those obtained for unadjusted scores ( $\mathrm{C}, \mathrm{P}$ and $\mathrm{M})$, whereas the opposite was observed for both minimum values and coefficients of variation. 
Table 1. Mean (M), standard deviation (SD), coefficient of variation (CV), minimum (MIN) and maximum (MAX), for unadjusted conformation $(\mathrm{C})$, precocity $(\mathrm{P})$, muscle $(\mathrm{M})$ scores and $\mathrm{Ci}$, Mi and Pi scores adjusted for weight at 450 days of age, for Nellore cattle.

\begin{tabular}{|c|c|c|c|c|c|}
\hline Traits & $\mathrm{M}$ & $\mathrm{SD}$ & CV (\%) & MIN & MAX \\
\hline $\mathrm{C}$ & 3.16 & 1.05 & 33.96 & 1.00 & 5.00 \\
\hline $\mathrm{P}$ & 3.13 & 1.15 & 37.30 & 1.00 & 5.00 \\
\hline M & 2.99 & 1.12 & 37.91 & 1.00 & 5.00 \\
\hline $\mathrm{Ci}$ & 3.36 & 1.14 & 33.17 & 0.83 & 5.89 \\
\hline $\mathrm{Pi}$ & 3.28 & 1.22 & 36.81 & 0.85 & 5.52 \\
\hline $\mathrm{Mi}$ & 3.14 & 1.19 & 37.44 & 0.85 & 5.55 \\
\hline
\end{tabular}

This trend is probably due to the score adjustment process, which corrects the same $\mathrm{C}, \mathrm{P}$ and $\mathrm{M}$ values attributed to animals of different ages at the time of evaluation. For example, when both an older (A) and younger (B) animal achieve a conformation score of " 1 ", the adjustment process corrects the score of the younger animal (B) to a higher value. This correction holds true for all scores, including "5".
The small values for coefficients of determination $\left(\mathrm{R}^{2}\right)$ obtained for all models $(0.0003$ to 0.4655$)$ indicate a poor fit of the estimated regression equations. Nevertheless, the effects of covariates, both linear and quadratic, significantly influenced $(\mathrm{P}<0.001)$ the scores of $\mathrm{C}, \mathrm{P}$ and $\mathrm{M}$ (Table 2). The model that included the age of cow at calving effect (AC) as a covariate displayed the lowest $\mathrm{R}^{2}$, although this was statistically significant (linear and quadratic effects).

Table 2. Summary of analysis of variance and estimated visual scores of conformation $(\mathrm{C})$, precocity $(\mathrm{P})$ and muscling (M) of Nellore at long yearling.

\begin{tabular}{|c|c|c|c|}
\hline \multirow{2}{*}{ Source of Variation } & \multicolumn{3}{|c|}{ Visual score } \\
\hline & $\mathrm{C}$ & $\mathrm{P}$ & $\mathrm{M}$ \\
\hline Intercept & $3.08 \mathrm{E}-6 \pm 3.97 \mathrm{E}-03$ & $-4.7518 \mathrm{E}-7 \pm 4.40 \mathrm{E}-03$ & $-1.19531 \mathrm{E}-9 \pm 4.28 \mathrm{E}-03$ \\
\hline AC Linear & $0.06848 * * \pm 7.27 \mathrm{E}-03$ & $-0.02966 * * \pm 8.05 \mathrm{E}-03$ & $-0.02521 * * \pm 7.85 \mathrm{E}-03$ \\
\hline AC Quadratic & $-4.93 \mathrm{E}-3 * * \pm 4.464 \mathrm{E}-04$ & $0.00148 * * \pm 4.95 \mathrm{E}-04$ & $0.00095300 * * \pm 4.82 \mathrm{E}-04$ \\
\hline DF Residue & 58944 & 58944 & 58944 \\
\hline Model MS/(R²) & $70.047 * * /(0.0026)$ & $11.021 * * /(0.0003)$ & $17.710 * * /(0.0006)$ \\
\hline Intercept & $-0.00035503 \pm 3.93$ E-03 & $-0.00018630 \pm 4.39 \mathrm{E}-03$ & $-0.00018448 \pm 4.27$ E-03 \\
\hline YA Linear & $0.03675 * * \pm 3.06 \mathrm{E}-03$ & $0.03363 * * \pm 3.42 \mathrm{E}-03$ & $0.03467 * * \pm 3.33 \mathrm{E}-03$ \\
\hline YA Quadratic & $-0.00002452 * * \pm 3.00 \mathrm{E}-06$ & $-0.00002585 * * \pm 3.30 \mathrm{E}-06$ & $-0.00002643 * * \pm 3.20 \mathrm{E}-06$ \\
\hline DF Residue & 58608 & 58608 & 58608 \\
\hline Model MS/(R²) & $733.749 * * /(0.0269)$ & $304.484 * * /(0.0091)$ & $340.693 * * /(0.0107)$ \\
\hline Intercept & $-0.00246 \pm 3.03 \mathrm{E}-03$ & $0.00097114 \pm 4.05 \mathrm{E}-03$ & $0.00077637 \pm 3.92 \mathrm{E}-03$ \\
\hline YW Linear & $0.04828 * * \pm 8.47 \mathrm{E}-04$ & $0.04642 * * \pm 1.13 \mathrm{E}-03$ & $0.04398 * * \pm 1.09 \mathrm{E}-03$ \\
\hline YW Quadratic & $-0.00003816 * * \pm 1.50$ E-06 & $-0.00004718 * * \pm 2.06 \mathrm{E}-06$ & $-0.00004217 * * \pm 2.00 \mathrm{E}-06$ \\
\hline DF Residue & 54932 & 54932 & 54932 \\
\hline Model MS/(R²) & $12091.000 * * /(0.4655)$ & $7049.067 * * /(0.2217)$ & $7185.077 * * /(0.2367)$ \\
\hline
\end{tabular}

$\mathrm{DF}=$ degrees of freedom; $\mathrm{MS}=$ mean square; $* *=\mathrm{P}<(0.001) ; \mathrm{AC}=$ age of dam at calving; $\mathrm{YA}=$ long yearling age; $\mathrm{YW}=$ long yearling weight; $\mathrm{R}^{2}=$ coefficient of determination. 
The YA and YW effects on the C, P and M scores were quadratic; however, the models that included YA as a covariate displayed much lower coefficients of determination $\left(\mathrm{R}^{2}\right)$ compared to those that included YW (Table 2). These results can be explained by the absorption of CG effect, whose definition involved factors related to yearling age, such as season and management group at birth.

The significant effect of YW $(\mathrm{P}<0.001)$ on visual scores may also be due to the technician's tendency to assign higher scores to animals with higher body weights, which would explain the higher coefficients of determination $\left(\mathrm{R}^{2}\right)$ for models including YW as covariate.

The correlation coefficients of $\mathrm{C}$ models for all covariates, $\mathrm{AC}$, YA and $\mathrm{YW}$, were higher than those of $\mathrm{M}$ models, which in turn were higher than those of P models. The intercept for all models was close to zero because the scores were corrected for the $\mathrm{CG}$ and score distribution took into account $\mathrm{CG}$ average.

The plots of the regression models (Figure 1) show great variation in the number of animals along the curves for YA and YW (Figure 1, from a to f) while value amplitudes caused larger standard error of the scores at both ends, where the amount of information is reduced. On the other hand, in the central region of the curves where the number of animals was higher, scores show quadratic behavior for both effects (YA and YW).

The effect of age of dam at calving on $\mathrm{C}$ (Figure $1, \mathrm{~g})$ showed a different trend compared to that of $\mathrm{P}$ and $\mathrm{M}$ (Figure 1, h and i), which were similar. Mature cows produce offspring with better $\mathrm{C}$ scores than younger and older dams. This effect displayed a trend on $\mathrm{C}$ score similar to that observed for body weight at weaning and long yearling weight of Nellore cattle, as reported by Koury Filho et al. (2010), probably because $\mathrm{C}$ score takes into account both animal size and the amount of muscle on the carcass. Similar trends for the AC effect on P and M scores (Figure 1, h and i) suggest that calves born from younger and older cows fared slightly better for both scores compared to calves from mature cows, thus suggesting a small compensatory gain after weaning. This trend has also been described to post-weaning weight gain in beef cattle (MUNIZ; QUEIROZ, 1999; KIPPERT et al., 2008).

Estimates of additive genetic, environmental and phenotypic variances of C, P and M (Table 3 ) varied among the models analyzed. The M3 model yielded lower estimates compared to the others. The M4 model provided intermediate variance estimates, whereas M2 and M1 models had the highest scores and were close in variance estimates values. This variation observed in the variance components can be explained by the inclusion of different covariates in the models.

Including the YA covariate in the M2 model did not change the heritability estimates for $\mathrm{C}, \mathrm{P}$ and $\mathrm{M}$ compared to the values estimated by the model without the covariate (M1, Table 3). This result can be attributed to the fact that the YA effect must have been greatly minimized by the inclusion of CG effect, which considered information related to animal age, such as the year and season of birth. Furthermore, the variance estimates changed considerably for models that included the YW effect, but since both additive genetic and environment variances changed, the estimate of heritability changed little, with the exception of $\mathrm{C}$ models, in which these estimates resulted in some change. 
Figure 1. Trend of $\mathrm{C}, \mathrm{P}$ and $\mathrm{M}$ scores at long yearling age for Nellore cattle, corrected for contemporary group, according to animal long yearling age, in months ( $a, b$ and c), animal weight, in kilograms (d, e and $f$ ) and age of dam at calving, in years ( $\mathrm{g}, \mathrm{h}$ and $\mathrm{i}$ ).
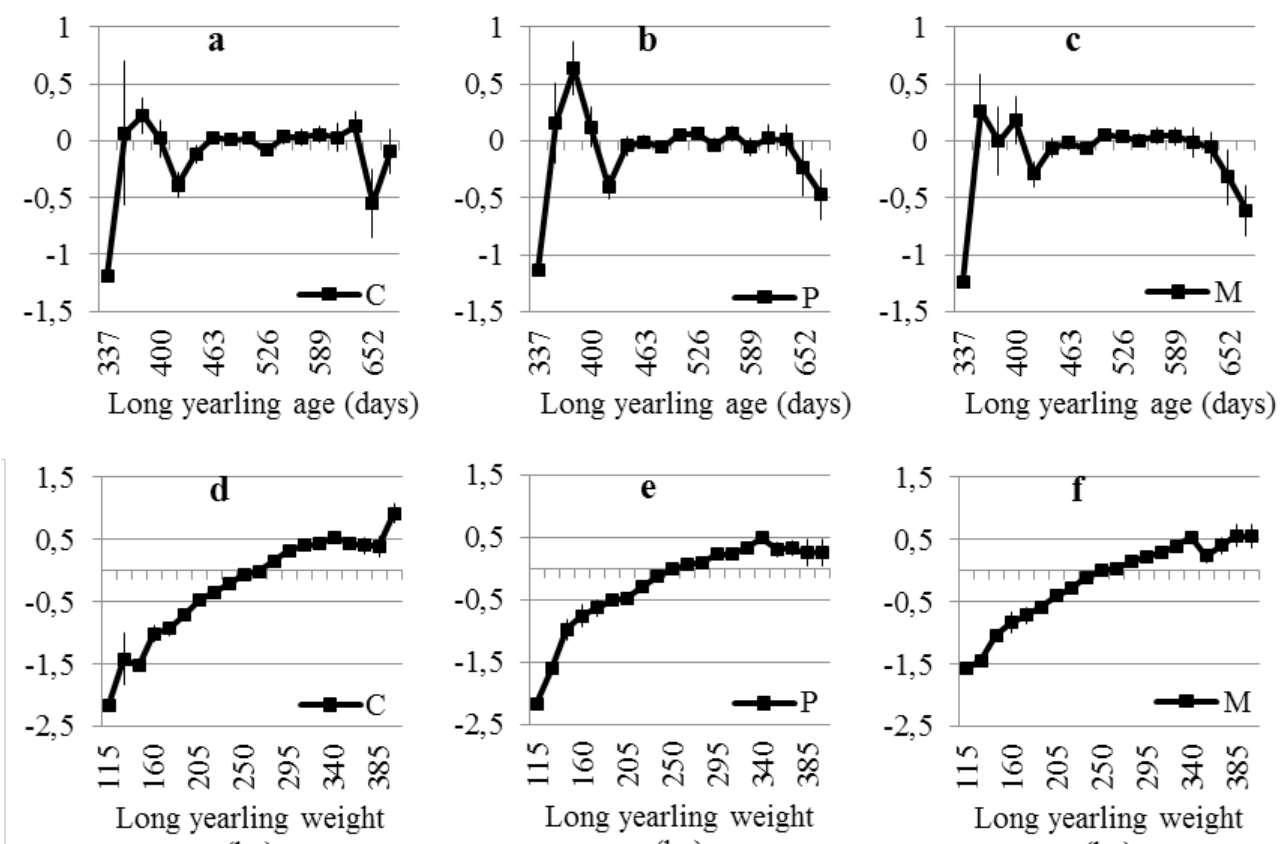

$(\mathrm{kg})$

$(\mathrm{kg})$

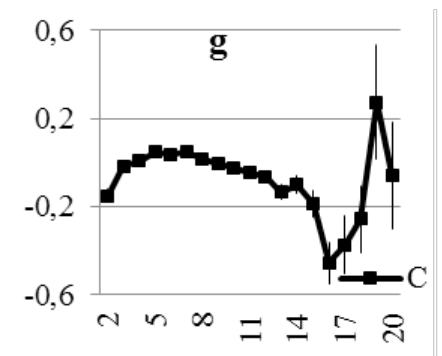

Age of dam at calving (year)

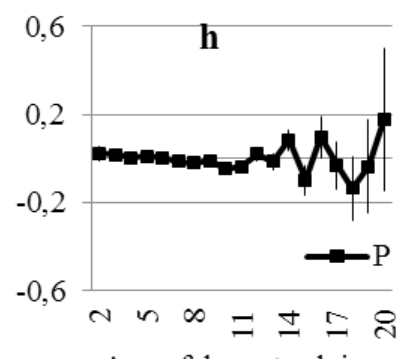

Age of dam at calving (year)

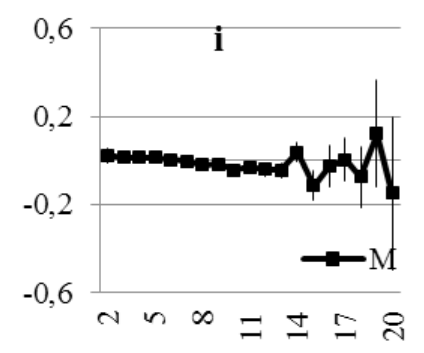

Age of dam at calving (year)

Table 3. Estimates of variance and heritability components considering four different models for conformation (C), precocity $(\mathrm{P})$ and muscling $(\mathrm{M})$ scores of Nellore at long yearling.

\begin{tabular}{ccccccc}
\hline \multirow{2}{*}{ Traits } & Models & $\sigma_{a}^{\mathbf{2}}$ & $\sigma_{\boldsymbol{\theta}}^{\mathbf{2}}$ & $\sigma_{p}^{\mathbf{2}}$ & $\mathrm{h}^{2}$ & SE \\
\hline \multirow{5}{*}{ Conformation } & M1 & 0.2985 & 0.7141 & 1.0126 & 0.29 & 0.022 \\
& M2 & 0.2867 & 0.7052 & 0.9919 & 0.29 & 0.023 \\
& M3 & 0.0888 & 0.6052 & 0.6939 & 0.13 & 0.015 \\
\multirow{3}{*}{ Precocity } & M4 & 0,1130 & 0.6951 & 0.8081 & 0,14 & 0.016 \\
\hline & M1 & 0.4419 & 0.7753 & 1.2172 & 0.36 & 0.022 \\
& M2 & 0.4374 & 0.7727 & 1.2101 & 0.36 & 0.022 \\
& M3 & 0.3399 & 0.7068 & 1.0467 & 0.32 & 0.021 \\
& M4 & 0.3785 & 0.7829 & 1.1614 & 0.33 & 0.021 \\
\hline
\end{tabular}




\begin{tabular}{|c|c|c|c|c|c|c|}
\hline & & & & & & Continue ... \\
\hline \multirow{4}{*}{ Muscling } & M1 & 0.4374 & 0.7148 & 1.1522 & 0.38 & 0.023 \\
\hline & M2 & 0.4315 & 0.7130 & 1.1446 & 0.38 & 0.022 \\
\hline & M3 & 0.3435 & 0.6325 & 0.9760 & 0.35 & 0.022 \\
\hline & M4 & 0.3845 & 0.7033 & 1.0878 & 0.35 & 0.022 \\
\hline
\end{tabular}

$\sigma_{a}^{\mathbf{2}}=$ additive genetic variance estimate; $\sigma_{a}^{\mathbf{2}}=$ environmental variance estimated; $\sigma_{p}^{\mathbf{2}}=$ phenotypic variance estimate; $\mathrm{h}^{2}=$ heritability, $\mathrm{SE}=$ standard error of the heritability estimate; $\mathrm{M} 1$ = model without covariate; $\mathrm{M} 2$ = model with long yearling age as covariate; M3 = model with long yearling weight as a covariate; M4 = model with long yearling weight as a covariate and C, P, M and long yearling.

The standard deviation values of $\mathrm{C}, \mathrm{P}$ and $\mathrm{M}$ scores (Table 1) were similar due to the fact that the scores were defined as discrete variables, with integer values ranging from 1 to 5 . Therefore, heterogeneous and homogeneous management groups (evaluation lots) show similar variations, which means that groups with large differences between scores " 1 " (worst animals) and " 5 " (best animals), and other groups with little differences between " 1 " and " 5 " have approximate variances for scores. However, the same trend is not observed for other continuous traits such as body weight. Thus, "too skinny" animals with "low scores" belong to heterogeneous management groups (with wide variation in weights) may have a genetic evaluation close to that of "lean" animals that belong to more homogeneous management groups (with less weight variation). Thus, in terms of genetic evaluation, the emaciated animals of the heterogeneous group can be considered inferior than the lean animals of the homogeneous groups. This differentiation was not as evident with the inclusion of animal age in the model, but was observed when long yearling weight was included in the model (Fig. 1). Therefore, not including the long yearling weight effect in the analyses may underestimate or overestimate the genetic parameters scores.

For the studied scores, it is usual to account only for the animal's age as a covariate, but the efficiency of including this effect decreases when the CG effect is taken into account as well, since it considers several factors related to animal age (year, month or season of birth). The lack of fitness observed for models considering long yearling age (YA) as a covariate can be verified by the small values for the coefficients of determination of this model (Table 2).

The M3 model with long yearling weight as a covariate highlighted the influence of weight on visual scores, mainly in C. In addition, a decrease of variances (environmental, phenotypic and additive) was also observed and heritability was estimated compared to others (Table 3).

The visual scores presented estimates of heritability $\left(\mathrm{h}^{2}\right)$ ranging from 0.13 to 0.38 (Table 3), with small standard errors. $\mathrm{P}$ and $\mathrm{M}$ scores showed similar heritability estimates for all models considered and larger than those estimated for $\mathrm{C}$. The heritability estimates for $\mathrm{C}, \mathrm{P}$ and $\mathrm{M}$ obtained in this study were close to those for Nellore breed reported by Eler et al. (1996) of 0.34, 0.29 and 0.33 , and Van Melis et al. (2003) of 0.22, 0.21 and 0.22 , respectively, and higher than those found by Koury Filho et al. (2010) of 0.13, 0.25 and 0.23, respectively, for the Nellore breed, and those found by Queiroz et al. (2011) of 0.12, 0.14 and 0.13, respectively, for Brangus cattle.

Estimates of Pearson and Spearman correlations based on sires' breeding values (Table 4), estimated according to different models, were of high magnitude, while the M3 and M4 models showed higher values that were similar to each other, meaning no practical difference between them. However, when M1 and M2 are compared with M3 and M4 models, the differences are more remarkable 
for both sires' ranking and the correlations between breeding values predicted by these models.

Pearson and Spearman correlation estimates of breeding values for $\mathrm{C}, \mathrm{P}$ and $\mathrm{M}$, considering M1 (without covariate) and M3 (long yearling weight as a covariate) models, were slightly lower than the others, especially for C. This is probably due to the fact the M2 and M4 models took into account the animal age as a covariate, so that the CG effect concatenating birth year and season and management group may have decreased the influence of this effect on these models.

Table 4. Estimates of Spearman (upper diagonal) and Pearson (lower diagonal) correlations between predicted breeding values for the visual scores of conformation, precocity and muscling of Nellore at long yearling age.

\begin{tabular}{lccccc}
\hline Traits & Models & M1 & M2 & M3 & M4 \\
\hline Conformation & M1 & 1 & $0.98784 *$ & $0.84544 *$ & $0.87808 *$ \\
& M2 & $0.98931 *$ & 1 & $0.84111^{*}$ & $0.88594 *$ \\
& M3 & $0.83737 *$ & $0.83398 *$ & 1 & $0.98474 *$ \\
& M4 & $0.87015 *$ & $0.87303 *$ & $0.98869 *$ & 1 \\
\hline Precocity & M1 & 1 & $0.99732 *$ & $0.96907 *$ & $0.97624 *$ \\
& M2 & $0.99894 *$ & 1 & $0.96663 *$ & $0.97510 *$ \\
& M3 & $0.97790 *$ & $0.97812 *$ & 1 & $0.99631 *$ \\
\hline Muscling & M4 & $0.98175 *$ & $0.98273 *$ & $0.99793 *$ & 1 \\
& M1 & 1 & $0.99751 *$ & $0.96731 *$ & $0.97756 *$ \\
& M2 & $0.99895 *$ & 1 & $0.96575 *$ & $0.97667 *$ \\
& M3 & $0.97699 *$ & $0.97652 *$ & 1 & $0.99620 *$ \\
& M4 & $0.98189 *$ & $0.98227 *$ & $0.99859 *$ & 1 \\
\hline
\end{tabular}

M1 = model without covariate; M2 = model with long yearling age as a covariate; M3 = model with long yearling weight as a covariate; M4 = model with long yearling weight as a covariate and C, P, M and yearling weight adjusted for 450 days of age, * $=$ $\mathrm{P}<(0.001)$.

The conformation scores (C) yielded correlation estimates of breeding values smaller than 0.9 in most models. On the other hand, precocity $(\mathrm{P})$ and muscling (M) scores displayed similar correlation values that were close to " 1 " (perfect correlation) in all cases (Table 4).

Because the definition of conformation (C) comprises the size of the animal, the estimated correlation between these two traits (size and C) is high compared to the correlations estimated between size and the other two traits (P and $\mathrm{M})$. Therefore, the inclusion of body weight effect in the models tended to change more for $\mathrm{C}$ compared to $\mathrm{P}$ and $\mathrm{M}$, the animal ranking according to their genetic values.

Figure 2 shows the ranking of the most representative sires of the dataset (with over 100 offspring, totaling 99 bulls) according to each model used. Breeding values for C, P and $\mathrm{M}$ obtained according to models M2, M3 and M4 are compared to those from model M1 (without covariate).

The sire ranking shows more remarkable changes for $\mathrm{C}$ score compared to $\mathrm{P}$ and $\mathrm{M}$ (Fig. 2). When $\mathrm{C}$ trait models included long yearling weight (YW) as a covariate (M3 and M4 models), the sire ranking changes were noticeable compared to M1. Sires that were ranked up to the 20th position according to model M1 reached the 70th position when evaluated by M3 and M4. This result may be due to the stronger relationship between body weight and $\mathrm{C}$, so that the inclusion of $\mathrm{YW}$ as a covariate in the model allowed for a more accurate evaluation of C. 
Figure 2. Ranking of sires with more than a hundred calves, according to their predicted breeding values for $\mathrm{C}, \mathrm{P}$ and M scores, comparing M1 model (without covariate) with M2 (long yearling age as a covariate), M3 (long yearling weight as a covariate) and M4 (long yearling weight as a covariate and C, P, M and long yearling weight adjusted for weight at 450 days of age).
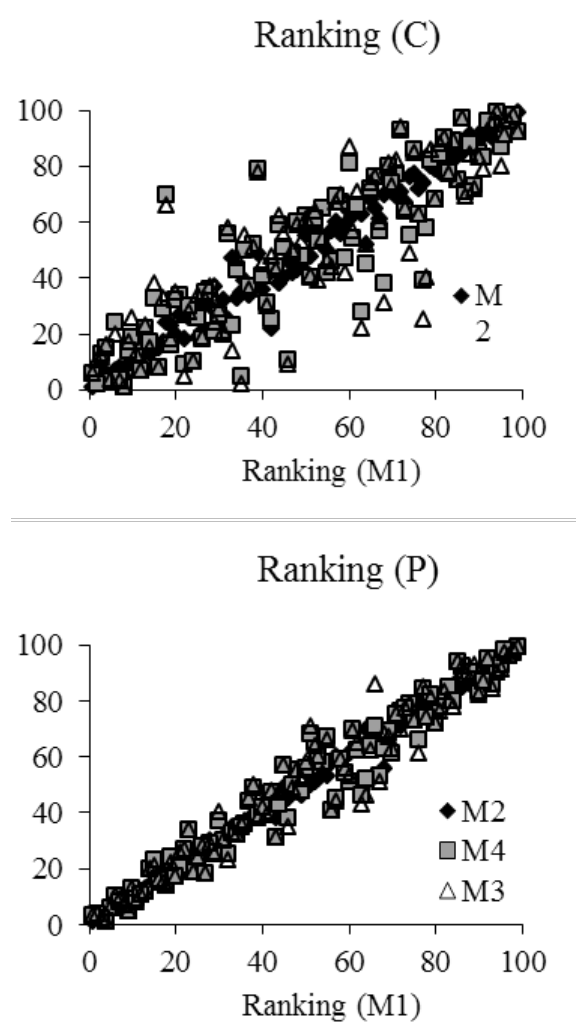

\section{Ranking (M)}

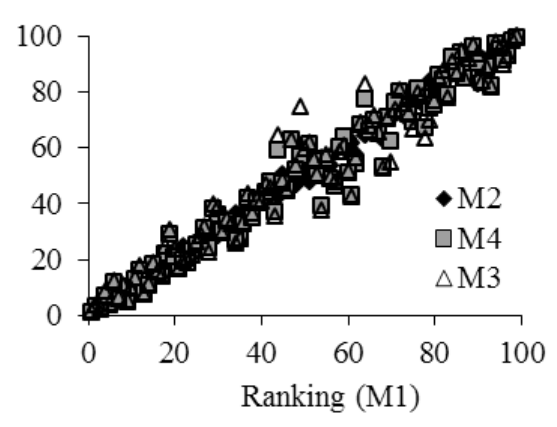

\section{Conclusion}

The significance of the effects of age of dam at calving, as well as animal age and weight at long yearling age must be verified before proceeding with the genetic evaluation of $\mathrm{C}, \mathrm{P}$ and $\mathrm{M}$ scores. The inclusion of these effects in the models changed the variance components and the ranking of sires based on their breeding values. C, P and M traits can respond to direct selection.

\section{Acknowledgements}

The authors are thankful to the PAINT® breeding program (CRV Lagoa Ltd.) for providing 
the data used in this study. DCBS was supported by FAPESP (Fundação de Amparo à Pesquisa do Estado de São Paulo) fellowship. SAQ was granted a fellowship from the CNPq (Conselho Nacional de Desenvolvimento Científico e Tecnológico).

\section{References}

BOLDMAN, K. G.; KRIESE, L. A.; VAN VLECK, L. D.; VAN TASSEL, C. P.; KACHMAN, S. D. A manual for use of MTDFREML: a set of programs to obtain estimates of variance and (co)variance (DRAFT). Lincoln: Department of Agriculture/ARS, 1995. 120 p.

CARDOSO, F. F.; CARDELlinO, R. A.; CAMPOS, L. T. Componentes de (co)variância e parâmetros genéticos de características pós-desmama em bovinos da raça Angus. Revista Brasileira de Zootecnia, Viçosa, MG, v. 33, n. 2, p. 313-319, 2004.

CARDOSO, V.; QUEIROZ, S. A.; FRIES, L. A. Estimativas de efeitos genotípicos sobre os desempenhos pré e pós-desmama de populações Hereford x Nelore. Revista Brasileira de Zootecnia, Viçosa, MG, v. 37, n. 10, p. 1763-1773, 2008.

CRV LAGOA. Sumário Consolidado PAINT 2013. Sertãozinho: Lagoa da Serra Ltda, 2013. Disponível em: <http://www.crvlagoa.com.br/EdicaoEletronica/ SumarioPaintconsolidado2013>. Acesso em: 05 nov. 2013.

DAL-FARRA, R. A.; ROSO, V. M.; SCHENKEL, F. S. Efeitos de ambiente e heterose sobre o ganho de peso do nascimento ao desmame e sobre os escores visuais ao desmame de bovinos de corte. Revista Brasileira de Zootecnia, Viçosa, MG, v. 31, p. 1350-1361, 2002. Suplemento.

ELER, J. P.; FERRAZ, J. B. S.; SILVA, P. R. Parâmetros genéticos para peso, avaliação visual e circunferência escrotal na raça Nelore, estimados por modelo animal. Arquivo Brasileiro de Medicina Veterinária e Zootecnia, Belo Horizonte, MG, v. 48, n. 2, p. 203-213, 1996.
KIPPERT, C. J.; RORATO, P. R. N.; LOPES, J. S.; WEBER, T.; BOLIGON, A. A. Efeitos genéticos aditivos diretos e maternos e heterozigóticos sobre os desempenhos pré e pós-desmama em uma população multirracial Aberdeen Angus x Nelore. Revista Brasileira de Zootecnia, Viçosa, MG, v. 37, n. 8, p. 1383-1391, 2008.

KOURY FILHO, W.; ALBUQUERQUE, L. G.; FORNI, S.; SILVA, J. A. II. V.; YOKOO, M. J.; ALENCAR, M. M. Estimativas de parâmetros genéticos para os escores visuais e suas associações com peso corporal em bovinos de corte. Revista Brasileira de Zootecnia, Viçosa, MG, v. 39, n. 5, p. 1015-1022, 2010.

LONG, R. A. El sistema de evaluación de Ankony y su aplicación en la mejora del ganado. Colorado: Ankony Corporation, 1973. $21 \mathrm{p}$.

MUNIZ, C. A. S. D.; QUEIROZ, S. A. Avaliação de características de crescimento pós-desmama de animais Nelore e seus cruzados no Mato Grosso do Sul. Revista Brasileira de Zootecnia, Viçosa, MG, v. 28, n. 4, p. 713720, 1999.

QUEIROZ, S. A.; COSTA, G. Z.; OLIVEIRA, J. A.; FRIES, L. A. Efeitos ambientais e genéticos sobre escores visuais e ganho de peso a desmama de animais formadores da raça Brangus. Revista Brasileira de Zootecnia, Viçosa, MG, v. 38, n. 2, p. 277-283, 2009.

QUEIROZ, S. A.; OlIVEIRA, J. A.; COSTA, G. Z.; FRIES, L. A. Estimates of genetic parameters for visual scores and daily weight gain in Brangus animals. Animal, Cambridge, v. 5, n. 6, p. 838-843, 2011.

VAN MELIS, M. H.; ELER, J. P.; SILVA, J. A. II. V.; FERRAZ, J. B. S. Estimação de parâmetros genéticos em bovinos de corte utilizando os métodos de máxima verossimilhança restrita e R. Revista Brasileira de Zootecnia, Viçosa, MG, v. 32, n. 6, p. 1624-1632, 2003. 